\title{
PERAN KOPERASI PERTANIAN (KOPTAN) MITRA SUBUR DALAM PENINGKATAN PENDAPATAN DAN KESEJAHTERAAN PETANI PADI DI KECAMATAN GUNUNG SUGIH KABUPATEN LAMPUNG TENGAH
}

\author{
(The Role of Mitra Subur Agricultural Cooperative in Increasing Rice Farmers' Income and Welfare in \\ Gunung Sugih sub-district, Central Lampung district)
}

Lussy Nurfitasary, Dyah Aring Hepiana Lestari, Ani Suryani

Jurusan Agribisnis, Fakultas Pertanian, Universitas Lampung, Jalan Prof. Dr. Soemantri Brojonegoro No. 1 Bandar Lampung 35145. e-mail: dyah.aring@fp.unila.ac.id

\begin{abstract}
The purposes of this research are to compare income of rice farming members and nonmembers of Mitra Subur Agricultural Cooperative, analyze the economic benefits received by members from the cooperative, the contribution of the cooperative economic benefits to members household income, the distribution of members and nonmembers household income, and compare the level of welfare of cooperative members and nonmembers. This research uses a case study method at Agricultural Cooperative of Mitra Subur subdistrict Gunung Sugih, the Central Lampung district and the number of respondents is sixty people that consist of members and nonmembers. Data of this research were collected in February - March 2018 and analyzed descriptively. The reseach results showed that the rice farming income of members and nonmembers of Mitra Subur Agricultural Cooperative in season one was significantly different, while in season two was not significantly different. The economic benefits of cooperative received by members was still considered low and the distribution of remaining business proceeds had not been carried out fairly. The contribution of the cooperative economic benefits to household income of rice farmers members was still relatively low. Additional income from activities outside of the rice farming resulted in higher income inequality of nonmember farmers, while the income inequality of member farmers was lower. Rice farmer members and nonmembers were in the prosperous category, but the welfare level of non members was higher than that of member farmers.
\end{abstract}

Key words: cooperative, income, member, nonmember

\section{PENDAHULUAN}

Koperasi mempunyai kedudukan dan fungsi yang penting dalam rangka pembangunan ekonomi bangsa Indonesia, dimana Indonesia memiliki tiga sektor kekuatan ekonomi dalam melaksanakan tatanan kegiatan perekonomian negara, yaitu sektor negara, sektor swasta dan sektor koperasi. Menurut Syahrudin (2003), melalui koperasi berbagai program pembangunan sektor pertanian dan industri rakyat yang pada umumnya dikelola pengusaha kecil bisa dijalankan dengan skala ekonomi yang lebih besar, lebih efisien dan efektif.

Menurut Dinas Koperasi dan UKM Provinsi Lampung (2016), jumlah koperasi di Provinsi Lampung sebanyak 5.121 unit. Kabupaten Lampung Tengah berada pada urutan ke tiga dengan jumlah koperasi yang dinyatakan aktif sebanyak $65,07 \%$ dan sisanya dinyatakan tidak aktif.
Menurut BPS Provinsi Lampung (2016), Kabupaten Lampung Tengah merupakan kabupaten dengan produksi padi tertinggi di Provinsi Lampung. Produksi padi terbesar ke dua berada di Kecamatan Gunung Sugih dengan jumlah produksi sebanyak 54.845 ton (BPS Kabupaten Lampung Tengah, 2017).

Koperasi Pertanian (KOPTAN) adalah koperasi yang anggota-anggotanya para petani. Adanya KOPTAN di pedesaan sangat penting untuk menimbulkan semangat para petani untuk meningkatkan produksi pertanian dan membantu petani dalam memasarkan produk pertaniannya.

Pertumbuhan KOPTAN sangat penting untuk menunjang peningkatan produksi pertanian di Provinsi Lampung. Meningkatnya produksi pertanian akan berpengaruh terhadap pendapatan dan kesejahteraan petani. Menurut Dinas Koperasi dan UMKM Provinsi Lampung (2015), jumlah KOPTAN di Provinsi Lampung sebanyak 720 unit dengan jumlah KOPTAN yang dinyatakan aktif 
hanya $29,58 \%$ dan sisanya dinyatakan tidak aktif. Hal tersebut menunjukkan bahwa jumlah KOPTAN di Provinsi Lampung semakin berkurang. Salah satu KOPTAN yang masih aktif hingga saat ini di Kabupaten Lampung Tengah ialah KOPTAN Mitra Subur.

Berdasarkan latar belakang tersebut maka penelitian ini bertujuan untuk membandingkan pendapatan usahatani padi anggota dan non anggota KOPTAN Mitra Subur, menganalisis manfaat ekonomi koperasi yang diterima anggota, kontribusi manfaat ekonomi koperasi terhadap pendapatan rumahtangga anggota, distribusi pendapatan rumahtangga anggota dan non anggota, dan membandingkan tingkat kesejahteraan anggota dan non anggota.

\section{METODE PENELITIAN}

Metode penelitian yang digunakan pada penelitian ini yaitu studi kasus. Penelitian ini dilakukan di KOPTAN Mitra Subur Kecamatan Gunung Sugih Kabupaten Lampung Tengah Provinsi Lampung. Jumlah anggota KOPTAN Mitra Subur sebanyak 121 anggota. Jumlah sampel dihitung dengan menggunakan rumus Arikunto (2002), dimana sampel diambil $25 \%$ dari populasi. Berdasarkan perhitungan tersebut diperoleh sampel sebanyak 30 orang petani anggota. Untuk petani non anggota diambil berdasarkan proporsi yang sama dengan sampel petani anggota, sehingga diperoleh sampel sebanyak 30 orang yang dipilih secara acak (Simple Random Sampling). Jadi jumlah sampel dalam penelitian ini adalah 60 orang. Jenis data yang digunakan dalam penelitian ini adalah data primer dan data sekunder. Metode analisis yang digunakan dalam penelitian ini adalah deskriptif kuantitatif.

\section{Analisis Pendapatan Usahatani Padi}

Pendapatan usahatani padi diperoleh dengan menghitung selisih antara penerimaan yang diterima dari hasil produksi padi dengan biaya produksi yang dikeluarkan dalam satu tahun dirumuskan sebagai berikut (Soekartawi, 2002):

$$
\begin{aligned}
\pi & =\mathrm{TR}-\mathrm{TC} \\
& =\mathrm{Y} . \mathrm{Py}-\sum \mathrm{Xi} . \mathrm{Pxi}-\mathrm{BTT} .
\end{aligned}
$$

\section{Keterangan:}

$$
\begin{array}{ll}
\pi & =\text { Pendapatan usahatani padi }(\mathrm{Rp}) \\
\mathrm{TR} & =\text { Total penerimaan usahatani padi }(\mathrm{Rp}) \\
\mathrm{TC} & =\text { Total biaya produksi }(\mathrm{Rp}) \\
\mathrm{Y} & =\text { Hasil produksi usahatani padi }(\mathrm{kg})
\end{array}
$$

Py $\quad=$ Harga hasil produksi usahatani padi $(\mathrm{Rp} / \mathrm{kg})$

$\mathrm{Xi}=$ Faktor produksi variabel (tenaga kerja, benih, pupuk, pestisida)

Pxi = Harga faktor produksi variabel (Rp)

BTT = Biaya tetap total usahatani padi $(\mathrm{Rp})$

Untuk mengetahui apakah usahatani padi yang dilakukan petani menguntungkan atau tidak, maka digunakan analisis imbangan penerimaan dan biaya dirumuskan sebagai berikut:

$$
\mathrm{R} / \mathrm{C}=\mathrm{PT} / \mathrm{BT}
$$

$$
\begin{aligned}
& \text { Keterangan: } \\
& \text { R/C = Nisbah antara penerimaan dan biaya } \\
& \text { PT } \quad=\text { Penerimaan total } \\
& \text { BT } \quad=\text { Biaya total }
\end{aligned}
$$

Kriteria pengukuran pada R/C (Return Cost Ratio) adalah:

a. Jika R/C >1, maka usahatani tersebut menguntungkan.

b. Jika $\mathrm{R} / \mathrm{C}=1$, maka usahatani tersebut berada pada titik impas (break even poin).

c. Jika $\mathrm{R} / \mathrm{C}<1$, maka usahatani tersebut tidak menguntungkan (rugi).

\section{Manfaat Ekonomi Koperasi}

Manfaat ekonomi koperasi (MEK) dibagi menjadi dua yaitu tunai dan diperhitungkan. MEK tunai diperoleh dari Sisa Hasil Usaha (SHU) yang diperoleh anggota dalam satu tahun, sedangkan MEK diperhitungkan diperoleh dari selisih bunga pinjaman di dalam koperasi dan di luar koperasi yang dihitung dengan rumus:

$$
\begin{aligned}
& \text { MEK }_{\text {tunai }}=\text { SHU (Rp/tahun). } \\
& \mathrm{MEK}_{\text {diperhitungkan }}=\text { selisih bunga pinjaman } \\
& \text { koperasi dan luar koperasi ...(4) } \\
& \text { MEK }_{\text {total }}=\text { MEK tunai }+ \text { MEK } \\
& \text { diperhitungkan }
\end{aligned}
$$

\section{Kontribusi Manfaat Ekonomi Koperasi terhadap Pendapatan Rumahtangga}

Samuel dalam Suratiyah (1994), menjelaskan bahwa pendapatan rumahtangga petani berasal dari pendapatan usahatani (on farm), pendapatan di luar usahatani (off farm), dan pendapatan di luar pertanian (non farm). Sumber pendapatan 
usahatani terdiri dari on farm utama (padi) dan on farm bukan utama (non padi), pendapatan lainlain yang diperoleh dari pendapatan pertanian di luar usahatani (off farm) dan pendapatan di luar pertanian (non farm), serta manfaat ekonomi kopreasi (MEK ${ }_{\text {tunai }}$, dengan rumus sebagai berikut:

$$
\begin{aligned}
\mathrm{P}_{\mathrm{rt}}= & \mathrm{P}_{\text {on farm utama }}+\mathrm{P}_{\text {on farm bukan utama }}+ \\
& \mathrm{P}_{\text {off farm }}+\mathrm{P}_{\text {non farm }}+\mathrm{P}_{\text {MEK tunai }}
\end{aligned}
$$

Keterangan:

$$
\begin{array}{ll}
\mathrm{P}_{\mathrm{rt}} & =\text { Pendapatan rumahtangga } \\
\mathrm{P}_{\text {on farm utama }} & =\text { Pendapatan dari usahatani padi } \\
\mathrm{P}_{\text {on farm bukan utama }}= & \text { Pendapatan } \text { non padi } \\
\mathrm{P}_{\text {off farm }} & =\text { Pendapatan pertanian di luar } \\
& \text { usahatani } \\
\mathrm{P}_{\text {non farm }} & =\text { Pendapatan di luar pertanian } \\
\mathrm{P}_{\text {MEK tunai }} & =\text { Pendapatan dari koperasi }
\end{array}
$$

Untuk mengetahui kontribusi manfaat ekonomi koperasi bagi anggota koperasi terhadap pendapatan rumah tangga dihitung dengan rumus:

$\mathrm{K}_{\mathrm{MEK}}=\left(\mathrm{MEK}_{\text {tunai }} / \mathrm{P}_{\mathrm{rt}}\right) \times 100 \%$

Keterangan:

$\mathrm{K}_{\mathrm{MEK}} \quad=$ Besarnya kontribusi manfaat ekonomi koperasi (MEK) terhadap pendapatan rumahtangga

MEK = Manfaat ekonomi koperasi (MEK tunai) Yang diterima anggota

$\mathrm{P}_{\mathrm{rt}} \quad=$ Pendapatan total rumah tangga (Rp/tahun)

\section{Analisis Distribusi Pendapatan}

Untuk mengetahui pemerataan pendapatan digunakan analisis distribusi pendapatan Gini Ratio yang dihitung dengan menggunakan rumus (Todaro, 1993):

$$
\mathrm{GR}=1-\sum_{\mathrm{i}}^{\mathrm{k}} \mathrm{f}_{\mathrm{i}} \mathrm{Y}_{\mathrm{i}-1}+\mathrm{Y}_{\mathrm{i}}
$$

Keterangan:

$\mathrm{f}_{\mathrm{i}}=$ proporsi jumlah rumahtangga penerima dalam

$$
\text { strata ke-i }
$$

$Y_{i}=$ proporsi secara kumulatif dari jumlah pendapatan rumahtangga sampai strata ke-i

$\mathrm{k}=$ jumlah strata

$1=$ konstanta
Untuk memberikan penilaian tinggi rendahnya ketimpangan distribusi pendapatan tersebut dilakukan dengan kriteria menurut Todaro (2000) sebagai berikut:

(a) Lebih dari 0,50, artinya ketimpangan pendapatan tinggi.

(b) Antara 0,35 dan 0,50, artinya ketimpangan pendapatan sedang.

(c) Kurang dari 0,35, artinya ketimpangan pendapatan rendah.

\section{Analisis Tingkat Kesejahteraan}

Analisis tingkat kesejahteraan menggunakan indikator kemiskinan menurut Bank Dunia. Bank Dunia menetapkan garis kemiskinan internasional yang dinyatakan dalam suatu mata uang tunggal (Common Currency), yakni dollar Amerika Serikat. Bank Dunia menetapkan garis kemiskinan internasional sebesar 1 dollar Amerika Serikat per kapita per hari.

\section{Perbandingan Pendapatan Usahatani Padi dan Tingkat Kesejahteraan Anggota dan Non Anggota KOPTAN Mitra Subur}

Untuk membandingkan rata-rata dua kelompok kasus dalam hal ini pendapatan usahatani padi anggota dan non anggota serta tingkat kesejahteraan anggota dan non anggota, digunakan analisis uji beda rata-rata parametrik IndependentSample $t$ Test. Batas signifikansi yang digunakan adalah $10 \%(0,10)$, sehingga apabila nilai signifikansi $<10 \%$ maka Ho ditolak, sebaliknya jika nilai signifikansi $>10 \%$ maka Ho diterima.

\section{HASIL DAN PEMBAHASAN}

\section{Karakteristik Responden}

Karakteristik responden dalam penelitian ini dilihat berdasarkan umur, tingkat pendidikan, pengalaman berusahatani, jumlah tanggungan keluarga, dan usaha lain-lain. Sebagian besar responden anggota tersebar pada kelompok umur 44-58 tahun (usia produktif) dengan tingkat pendidikan rata-rata tamat SD serta memiliki tanggungan keluarga sebanyak $1-2$ orang $(53,55 \%)$. 
Tabel 1. Analisis pendapatan usahatani padi anggota dan non anggota KOPTAN Mitra Subur per hektar

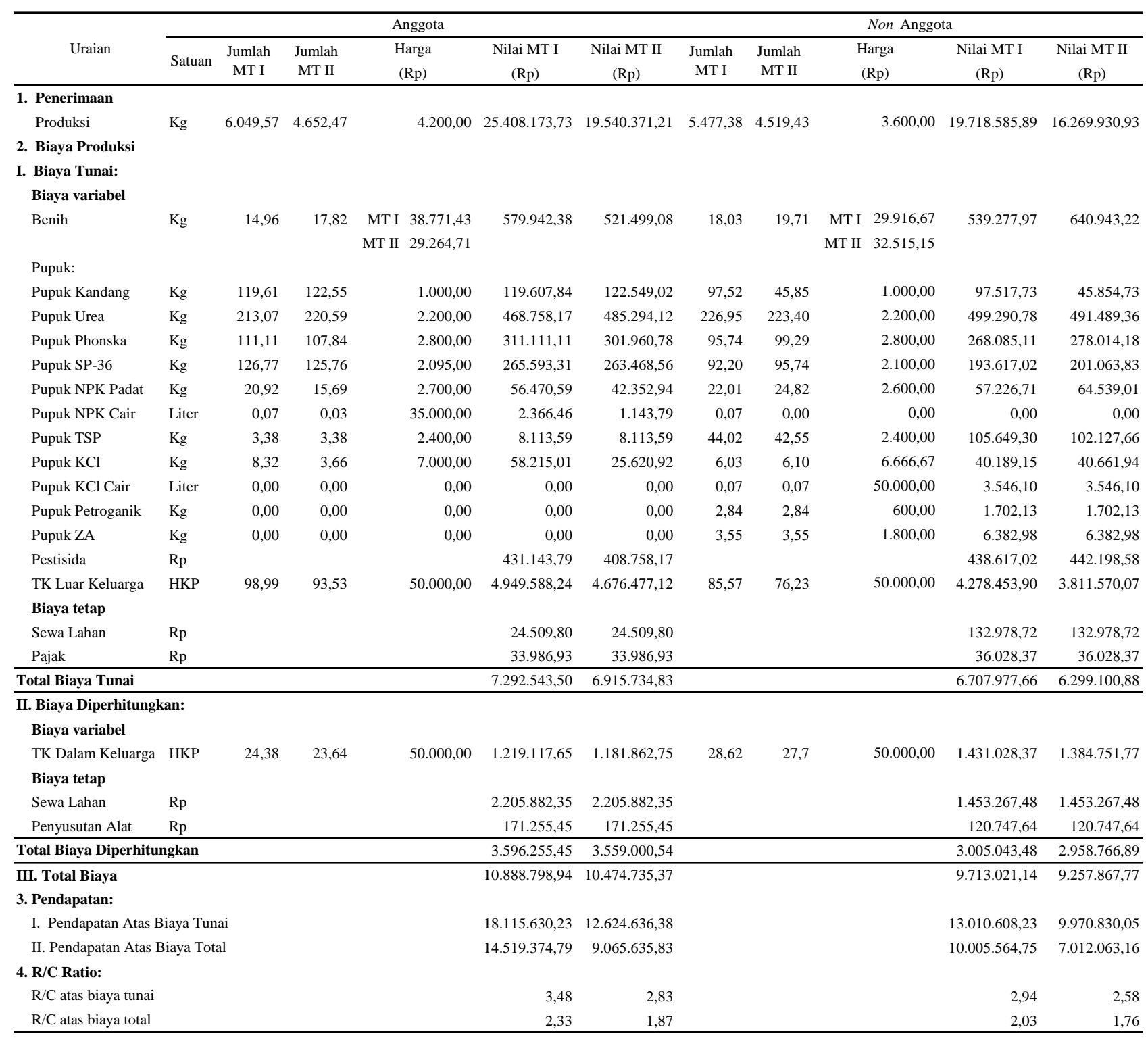

Pengalaman berusahatani responden anggota antara 21-35 tahun $(66,67 \%)$ dan usaha lain-lain yang diusahakan petani responden anggota ialah on farm bukan utama (singkong), off farm (buruhtani), non farm (pedagang), dan menjadi anggota koperasi.

Untuk responden non anggota, mayoritas tersebar pada kelompok umur 44-58 tahun (usia produktif) dan 58-72 tahun (usia tidak produktif) dengan tingkat pendidikan rata-rata tamat SMP serta memiliki tanggungan keluarga sebanyak 1-2 orang (70\%). Pengalaman berusahatani responden non anggota antara 21-35 tahun dan 36-50 tahun $(43,33 \%)$ dan usaha lain-lain yang diusahakan oleh petani responden non anggota ialah on farm bukan utama (singkong), off farm (buruhtani), dan non farm (bengkel).

\section{Analisis Pendapatan Usahatani Padi}

Berdasarkan Tabel 1 dapat dilihat bahwa nilai R/C atas biaya tunai dan $\mathrm{R} / \mathrm{C}$ atas biaya total pendapatan usahatani padi per hektar petani anggota dan petani non anggota KOPTAN Mitra Subur yang dilakukan pada musim tanam I dan musim tanam II lebih besar dari satu yang berarti usahatani padi yang dijalankan secara ekonomi menguntungkan dan layak untuk diusahakan. Penelitian ini didukung hasil penelitian yang dilakukan oleh Ivans, Zakaria, dan Yanfika (2013) di Kecamatan Purbolinggo Kabupaten Lampung Timur dengan nilai $\mathrm{R} / \mathrm{C}$ yang diperoleh sebesar 2,17 untuk musim gadu. Hal tersebut menunjukkan kesamaan kelayakan usaha yang 
dijalankan petani padi di daerah lain.

Tabel 2. Manfaat Ekonomi Koperasi (MEK) yang diterima anggota KOPTAN Mitra Subur

\begin{tabular}{lcc}
\hline \multicolumn{1}{c}{ Manfaat Ekonomi } & $\begin{array}{c}\text { Jumlah } \\
\text { (Rp/tahun) }\end{array}$ & $\begin{array}{c}\text { Persentase } \\
(\%)\end{array}$ \\
\hline Tunai & $170.000,00$ & 79,63 \\
SHU & & \\
\hline $\begin{array}{l}\text { Diperhitungkan } \\
\text { Selisih bunga } \\
\text { Pinjaman }\end{array}$ & $43.500,00$ & 20,37 \\
\hline Total MEK & & \\
\hline
\end{tabular}

\section{Manfaat Ekonomi Koperasi}

Manfaat ekonomi koperasi secara tunai yang diterima oleh anggota KOPTAN Mitra Subur berupa sisa hasil usaha (SHU), sedangkan manfaat ekonomi koperasi diperhitungkan berupa selisih bunga pinjaman koperasi dengan bunga pinjaman di luar koperasi.

Besarnya alokasi SHU untuk anggota KOPTAN Mitra Subur sesuai ketentuan yang telah ditentukan pada saat RAT sebesar 40 persen yang dibagi dengan seluruh anggota secara merata. Hal tersebut tidak sesuai dengan prinsip koperasi dimana seharusnya SHU dibagikan kepada anggota sebanding dengan jasa usaha yang dilakukan oleh masing-masing anggota kepada koperasi. Pada tahun 2017, bunga pinjaman di koperasi sebesar 8 persen. Bunga pinjaman pada alternatif tempat peminjaman anggota, antara lain meminjam di tetangga (0 persen), tengkulak (0 persen) dan BRI (12 persen).

Berdasarkan Tabel 2 terlihat bahwa persentase manfaat ekonomi tunai yang diterima oleh anggota KOPTAN Mitra Subur lebih besar dibandingkan dengan manfaat ekonomi diperhitungkan.

Tabel 3. Struktur pendapatan rumahtangga petani anggota dan non anggota KOPTAN Mitra Subur

\begin{tabular}{lcrcr}
\hline \multirow{2}{*}{$\begin{array}{c}\text { Jenis } \\
\text { pekerjaan }\end{array}$} & $\begin{array}{c}\text { Anggota } \\
\text { (Rp/tahun) }\end{array}$ & $\begin{array}{c}\text { Persentase } \\
(\%)\end{array}$ & $\begin{array}{c}\text { Non Anggota } \\
\text { (Rp/tahun) }\end{array}$ & $\begin{array}{r}\text { Persentase } \\
(\%)\end{array}$ \\
\hline $\begin{array}{l}\text { on farm } \\
\text { utama (padi) }\end{array}$ & $30.957 .230,99$ & 45,86 & $24.068 .783,05$ & 42,08 \\
$\begin{array}{l}\text { on farm } \\
\text { bukan utama } \\
\text { (non padi) }\end{array}$ & $7.369 .333,33$ & 10,92 & $4.856 .095,24$ & 8,49 \\
off farm & $6.960 .000,00$ & 10,31 & $13.330 .000,00$ & 23,31 \\
non farm & $22.048 .000,00$ & 32,66 & $14.940 .000,00$ & 26,12 \\
MEK tunai & $170.000,00$ & 0,25 & 0,00 & 0,00 \\
\hline Jumlah & $67.504 .564,32$ & 100,00 & $57.194 .878,28$ & 100,00 \\
\hline
\end{tabular}

Manfaat ekonomi koperasi yang diterima anggota KOPTAN Mitra Subur masih tergolong rendah jika dibandingkan dengan hasil penelitian Dinata, Lestari, dan Yanfika (2014) yang melakukan penelitian di Koperasi Tani Makmur Desa Natar Kebupaten Lampung Selatan, dimana manfaat ekonomi koperasi yang diterima anggota yaitu sebesar Rp 444.116,67. Hal ini dikarenakan pada penelitian tersebut terdapat harga pelayanan dari pembelian sarana produksi pertanian, sedangkan pada penelitian ini hanya selisih bunga pinjaman.

\section{Kontribusi MEK terhadap Pendapatan Rumahtangga Petani Anggota}

Sumber pendapatan keluarga petani berasal dari pendapatan usahatani (on farm) yang terdiri dari pendapatan on farm utama (padi) dan on farm bukan utama (non padi), pendapatan di luar usahatani (off farm), dan pendapatan di luar pertanian (non farm). Untuk petani anggota KOPTAN Mitra Subur memperoleh pendapatan tambahan dari manfaat ekonomi koperasi tunai.

Berdasarkan Tabel 3 dapat dijelaskan bahwa sumber pendapatan anggota dan non anggota dari usaha on farm utama (padi) memiliki kontribusi terbesar. Terdapat perbedaan besarnya total pendapatan rumahtangga antara petani responden anggota dan non anggota. Hal itu karena pendapatan dari manfaat ekonomi koperasi memberikan kontribusi sebesar 0,25 persen terhadap total pendapatan rumahtangga petani responden.

Perhitungan kontribusi manfaat ekonomi koperasi digunakan untuk mengetahui seberapa besar manfaat ekonomi koperasi tunai yang mempengaruhi besarnya jumlah pendapatan rumahtangga petani responden anggota koperasi.

Berdasarkan Tabel 3 dapat dilihat bahwa kontribusi manfaat ekonomi koperasi terhadap 
pendapatan rumahtangga petani padi anggota KOPTAN Mitra Subur sebesar 0,25 persen dari total pendapatan rumahtangga. Kontribusi manfaat ekonomi koperasi yang diperoleh anggota KOPTAN Mitra Subur masih tergolong rendah jika dibandingkan dengan hasil penelitian yang dilakukan oleh Agusta, Lestari, dan Situmorang (2014) di KPBS Pangalengan, dimana kontribusi manfaat ekonomi koperasi yang diterima oleh peternak anggota KPBS sebesar 5,35\% dari total pendapatan rumahtangga. Hal ini dikarenakan pada penelitian tersebut koperasi memiliki lebih dari satu unit usaha, sedangkan pada KOPTAN Mitra Subur hanya memiliki satu unit usaha yaitu simpan pinjam, sehingga mempengaruhi besarnya selisih hasil usaha yang diterima petani responden anggota koperasi.

\section{Analisis Distribusi Pendapatan}

Menurut Todaro (1993), berdasarkan hasil perhitungan distribusi pendapatan (Gini Ratio)

dapat diketahui apakah terjadi pemerataan pendapatan diantara rumahtangga petani pada suatu agroekosistem atau sebaliknya apakah terjadi ketimpangan pendapatan.

Pada Tabel 4 dapat dilihat bahwa ketimpangan pendapatan on farm utama petani anggota berada pada kriteria tinggi sebesar 0,51. Ketimpangan pendapatan semakin rendah ketika adanya tambahan pendapatan dari kegiatan on farm bukan utama, off farm, non farm, dan menjadi anggota koperasi. Hal tersebut didukung dengan hasil penelitian Mudakir B (2011), dimana nilai Gini Ratio pendapatan pertanian dengan adanya pendapataan di luar pertanian ketimpangan pendapatan menjadi lebih kecil. Selain itu, penelitian ini sesuai dengan penelitian Gusti, Haryono, dan Prasmatiwi (2013) di Desa Pesawaran Indah Kecamatan Padang Cermin, dimana petani kakao yang mengalami ketimpangan pendapatan sedang dengan nilai Gini Ratio sebesar 0,46 . Ketimpangan yang sedang dikarenakan sumber pendapatan bersumber dari on farm, off farm, dan non farm untuk menambah sumber pendapatan petani. Pendapatan tambahan dari manfaat ekonomi koperasi tidak berpengaruh terhadap distribusi pendapatan petani anggota koperasi, karena ketimpangan pendapatan petani anggota tetap berada pada kriteria sedang $(0,50)$.

Tabel 4. Distribusi pendapatan petani padi anggota dan non anggota KOPTAN Mitra Subur

\begin{tabular}{cccccc}
\hline & \multicolumn{5}{c}{ Kriteria } \\
\cline { 3 - 6 } No $\begin{array}{c}\text { Akumulasi pendapatan } \\
\text { menurut pekerjaan }\end{array}$ & \multicolumn{2}{c}{ GR } & \multicolumn{2}{c}{ Todaro } \\
\cline { 2 - 6 } & Anggota $\begin{array}{c}\text { Non } \\
\text { Anggota }\end{array}$ & Anggota & $\begin{array}{c}\text { Non } \\
\text { Anggota }\end{array}$ \\
\hline 1 On farm utama & 0,51 & 0,47 & Tinggi & Sedang \\
$2 \begin{array}{l}\text { On farm utama+bukan } \\
\text { utama }\end{array}$ & 0,51 & 0,49 & Tinggi & Sedang \\
$3 \begin{array}{l}\text { On farm (utama+bukan } \\
\text { utama)+Off farm }\end{array}$ & 0,51 & 0,57 & Tinggi & Tinggi \\
$\begin{array}{l}\text { On farm (utama+bukan } \\
4 \text { utama)+Off farm+Non } \\
\text { farm }\end{array}$ & 0,50 & 0,55 & Sedang & Tinggi \\
$\begin{array}{l}\text { Pendapatan rumahtangga } \\
\text { (+MEKtunai) }\end{array}$ & 0,50 & 0,55 & Sedang & Tinggi \\
\hline
\end{tabular}

Tabel 5. Tingkat kesejahteraan petani anggota KOPTAN Mitra Subur berdasarkan indikator Bank Dunia

\begin{tabular}{lcccr}
\hline \multirow{2}{*}{ Kategori } & \multicolumn{2}{c}{$\begin{array}{c}\text { Rata-rata Pengeluaran } \\
\text { per kapita per hari }\end{array}$} & \multicolumn{2}{c}{$\begin{array}{c}\text { Jumlah } \\
\text { (orang) }\end{array}$} \\
\cline { 2 - 6 } & Anggota & $\begin{array}{c}\text { Non } \\
\text { Anggota }\end{array}$ & Anggota & $\begin{array}{c}\text { Non } \\
\text { Anggota }\end{array}$ \\
\hline Tidak Sejahtera $<$ U\$1 & $10.718,19$ & 0,00 & 4 & 0 \\
Sejahtera $>$ U\$1 & $25.059,13$ & $31.085,88$ & 26 & 30 \\
\hline Jumlah & & & 30 & 30 \\
\hline *Kurs tahun 2017 (U\$1 = 13.616,00) & & &
\end{tabular}

Ketimpangan pendapatan on farm utama petani non anggota berada pada kriteria sedang sebesar 0,47 . Ketimpangan pendapatan semakin tinggi ketika adanya tambahan pendapatan dari kegiatan on farm bukan utama, off farm, dan non farm. Sedikitnya petani non anggota yang menjalankan usaha non farm dan pendapatan yang berbeda merupakan penyebab semakin tingginya ketimpangan pendapatan petani non anggota. Hal ini sesuai dengan penelitian yang dilakukan oleh Canita, Haryono, dan Kasymir (2017) di Desa Padang Cermin pada petani pisang dimana nilai Gini Ratio pendapatan petani pisang sebesar 0,53 yang menunjukkan ketimpangan distribusi pendapatan tinggi yang dikarenakan pendapatan rumahtangga petani di Desa Padang Cermin cenderung memiliki pendapatan rumahtangga yang berbeda.

\section{Analisis Tingkat Kesejahteraan Anggota dan Non Anggota}

Kesejahteraan berdasarkan indikator Bank Dunia diukur melalui pendekatan pengeluaran dengan dua kategori yaitu miskin dan tidak miskin. Suatu rumahtangga dikatakan miskin apabila pengeluaran rumahtangga kurang dari U\$1 per kapita per hari. Sebaliknya, rumahtangga dikatakan tidak miskin jika pengeluaran rumahtangga lebih dari U\$1 per kapita per hari. 
Pada Tabel 5 dapat dijelaskan bahwa petani responden anggota dan non anggota KOPTAN Mitra Subur mayoritas sudah masuk dalam kategori sejahtera, tetapi ada petani anggota yang masuk dalam kategori tidak sejahtera. Adanya petani anggota yang tidak sejahtera, dikarenakan pengeluaran rumahtangga petani anggota kurang dari U\$1 per kapita per hari yang dipengaruhi oleh jumlah tanggungan keluarga.

Hasil penelitian ini sebanding dengan hasil penelitian Okpratiwi, Haryono, dan Adawiyah (2018) di Kecamatan Gedong Tataan Kabupaten Pesawaran dimana petani yang sejahtera jauh lebih banyak dibandingkan petani yang tidak sejahtera.

\section{Perbandingan Pendapatan Usahatani Padi Anggota dan Non Anggota KOPTAN Mitra Subur}

Pada Tabel 6 menunjukkan nilai t sebesar 3,481 dengan tingkat kepercayaan sebesar $1 \%$ atau tingkat kepercayaan < 10\%, maka Ho ditolak, artinya pada musim tanam I terdapat perbedaan yang signifikan antara pendapatan usahatani padi anggota dan pendapatan usahatani padi non anggota dengan tingkat kepercayaan 99\%. Adanya perbedaan pendapatan usahatani padi pada musim tanam I anggota dan non anggota dikarenakan perbedaan luas lahan usahatani anggota dan non anggota serta sarana produksi yang digunakan yang berpengaruh terhadap biaya produksi usahatani dan pendapatan usahatani padi yang diperoleh.

Pada Tabel 7 menunjukkan nilai t sebesar 1,111 dengan tingkat kepercayaan sebesar $72,9 \%$ atau tingkat kepercayaan >10\%, maka Ho diterima, artinya pada musim tanam II tidak terdapat perbedaan yang signifikan antara pendapatan usahatani padi anggota koperasi dan pendapatan usahatani padi non anggota koperasi. Hal tersebut dikarenakan lahan usahatani petani anggota dan petani non anggota merupakan sawah tadah hujan sehingga pada musim tanam II (musim gadu/kemarau) risiko gagal panen serta terjangkit hama dan penyakit lebih besar yang mengakibatkan kebutuhan pestisida bertambah yang berpengaruh terhadap besarnya biaya usahatani petani anggota dan petani non anggota.

Tabel 6. Hasil analisis uji beda rata-rata pendapatan usahatani padi per hektar anggota dan non anggota KOPTAN Mitra Subur pada MT I

\begin{tabular}{lcccc}
\hline & \multicolumn{2}{c}{ Uji Lavene untuk } & \multicolumn{2}{c}{ t-test untuk } \\
kesetaraan varians & \multicolumn{2}{c}{ kesetaraan means } \\
\hline Perlakukan & F & Sig. & T & $\begin{array}{c}\text { Sig. (2- } \\
\text { tailed) }\end{array}$ \\
\hline $\begin{array}{l}\text { Varians } \\
\text { diasumsikan }\end{array}$ & 0,299 & 0,587 & 3,481 & 0,001 \\
$\begin{array}{l}\text { sama } \\
\text { Varians } \\
\text { diasumsikan } \\
\text { tidak sama }\end{array}$ & & & & \\
\hline
\end{tabular}

Tabel 7. Hasil analisis uji beda rata-rata pendapatan usahatani padi per hektar anggota dan non anggota KOPTAN Mitra Subur pada MT II

\begin{tabular}{lcccc}
\hline & $\begin{array}{c}\text { Uji Lavene } \\
\text { untuk kesetaraan } \\
\text { varians }\end{array}$ & \multicolumn{2}{c}{$\begin{array}{c}\text { t-test untuk } \\
\text { kesetaraan means }\end{array}$} \\
\hline \multicolumn{1}{c}{ Perlakukan } & F & Sig. & T & $\begin{array}{c}\text { Sig. (2- } \\
\text { tailed) }\end{array}$ \\
\hline $\begin{array}{l}\text { Varians } \\
\text { diasumsikan }\end{array}$ & 3,204 & 0,079 & 1,111 & 0,271 \\
$\begin{array}{l}\text { sama } \\
\text { Varians } \\
\text { diasumsikan } \\
\text { tidak sama }\end{array}$ & & & & \\
\hline
\end{tabular}

\section{Perbandingan Tingkat Kesejahteraan Anggota dan Non Anggota KOPTAN Mitra Subur}

Pada Tabel 8 menunjukkan nilai t sebesar $-2,908$ dengan tingkat kepercayaan sebesar 5\% atau tingkat kepercayaan < 10\% maka Ho ditolak, artinya terdapat perbedaan yang signifikan antara tingkat kesejahteraan petani anggota dan tingkat kesejahteraan petani non anggota dengan tingkat kepercayaan sebesar 95\%. Perbedaan tingkat kesejahteraan antara petani anggota dan non anggota disebabkan perbedaan jumlah tanggungan keluarga, dimana rata-rata jumlah tanggungan keluarga petani anggota yang tidak sejahtera antara 4-5 orang, sedangkan jumlah tanggungan keluarga petani non anggota antara 1-2 orang. Jumlah tanggungan keluarga sangat mempengaruhi tingkat kesejahteraan petani anggota dan non anggota koperasi.

\section{KESIMPULAN}

Pendapatan usahatani padi anggota dan non anggota KOPTAN Mitra Subur pada musim tanam I berbeda nyata, sedangkan pada musim tanam II tidak berbeda nyata. Manfaat ekonomi koperasi yang diterima anggota KOPTAN Mitra Subur 
Tabel 8. Hasil analisis uji beda tingkat kesejahteraan petani responden anggota dan non anggota KOPTAN Mitra Subur

\begin{tabular}{lcccc}
\hline & $\begin{array}{c}\text { Uji Lavene } \\
\text { untuk kesetaraan } \\
\text { varians }\end{array}$ & \multicolumn{2}{c}{$\begin{array}{c}\text { t-test untuk } \\
\text { kesetaraan means }\end{array}$} \\
\hline \multicolumn{1}{c}{ Perlakukan } & F & Sig. & T & $\begin{array}{c}\text { Sig. (2- } \\
\text { tailed) }\end{array}$ \\
\hline $\begin{array}{l}\text { Varians } \\
\text { diasumsikan }\end{array}$ & 2,670 & 0,108 & $-2,908$ & 0,005 \\
$\begin{array}{l}\text { sama } \\
\text { Varians } \\
\text { diasumsikan } \\
\text { tidak sama }\end{array}$ & & & & \\
\hline
\end{tabular}

masih tergolong rendah dan pembagian SHU belum dilakukan secara adil. Kontribusi manfaat ekonomi koperasi terhadap pendapatan rumahtangga petani anggota KOPTAN Mitra Subur masih tergolong rendah. Tambahan pendapatan dari kegiatan di luar usahatani padi mengakibatkan ketimpangan pendapatan petani non anggota semakin tinggi, sedangkan ketimpangan pendapatan petani anggota semakin rendah. Petani padi anggota dan non anggota KOPTAN Mitra Subur mayoritas sudah dalam kategori sejahtera, tetapi tingkat kesejahteraan petani non anggota lebih tinggi dibandingkan dengan petani anggota.

\section{DAFTAR PUSTAKA}

Agusta QTM, Lestari DAH, Situmorang S. 2014. Analisis Pendapatan dan Tingkat Kesejahteraan Rumah Tangga Peternak Sapi Perah Anggota Koperasi Peternakan Bandung Selatan (KPBS) Pangalengan. JIIA,2(2):109117.

http://jurnal.fp.unila.ac.id/index.php/JIIA/articl e/view/734/675. Diakses pada tanggal 28 Oktober 2017.

Arikunto S. 2002. Metode Penelitian Suatu Pendekatan Proposal. PT. Rineka Cipta. Jakarta.

Badan Pusat Statistik Kabupaten Lampung Tengah. 2017. Produksi Padi menurut Kecamatan di Kabupaten Lampung Tengah. Badan Pusat Statistik Kabupaten Lampung Tengah. Lampung.

Badan Pusat Statistik Provinsi Lampung. 2016. Produksi padi menurut kabupaten/kota provinsi Lampung. Badan Pusat Statistik Provinsi Lampung. Lampung.

Canita PL, Haryono D, dan Kasymir E. 2017.
Analisis Pendapatan dan Tingkat Kesejahteraan Rumah Tangga Petani Pisang di Kecamatan Padang Cermin Kabupaten Pesawaran. JIIA,5(3):

235-241. http://jurnal.fp.unila.ac.id/index.php/JIA/articl e/download/1635/1461. Diakses pada tanggal 22 Januari 2018.

Dinas Koperasi dan UKM Provinsi Lampung. 2016. Rekapitulasi Data Berdasarkan Tingkat Provinsi. Dinas Koperasi dan UKM Provinsi Lampung. Bandar Lampung.

Dinata AS, Lestari DAH, dan Yanfika H. 2014. Peran Koperasi Simpan Pinjam Tani Makmur dalamPeningkatan Pendapatan Rumah Tangga Petani Jagung di Desa Natar Kabupaten Lampung Selatan. JIIA, 2(3): 206-213. http://jurnal.fp.unila.ac.id/index.php/JIA/articl e.view/802/732. Diakses pada tanggal 19 Desember 2017.

Gusti AI, Haryono D, dan Prasmatiwi FE. 2013. Analisis Pendapatan dan Tingkat Kesejahteraan Rumah Tangga Petani Kakao di Desa Pesawaran Indah Kecamatan Padang Cermin Kabupaten Pesawaran. JIIA, 1(4): 278-283.

http://jurnal.fp.unila.ac.id/index.php/JIA/articl e/download/701/643. Diakses pada tanggal 18 Desembed 2017.

Ivans E, Zakaria WA, dan Yanfika H. 2013. Analisis Produksi dan Pendapatan Usahatani Padi Sawah di Kecamatan Purbolinggo Kabupaten Lampung Timur. JIIA, 1(3) : 238245.

http://jurnal.fp.unila.ac.id/index.php/JIA/articl e/view/579/541. Diakses pada tanggal 19 Desember 2017.

Mudakir B. 2011. Produktivitas Lahan dan Distribusi Pendapatan Berdasarkan Status Penguasaan Lahan pada Usahatani Padi (Kasus di Kabupaten Kendal Provinsi Jawa Tengah). Jurnal Dinamika Ekonomi Pembangunan, 1(1) : 74-83. http://ejournal.undip.ac.id. Diakses pada tanggal 18 Desember 2017.

Okpratiwi S, Haryono D, dan Adawiyah R. 2018. Analisis Pendapatan dan Tingkat Kemiskinan Rumahtangga Petani Kakao di Kecamatan Gedong Tataan Kabupaten Pesawaran. JIIA, 6(1):9-16.

http://jurnal.fp.unila.ac.id/index.php/JIA/articl e/download/2491/2177. Diakses pada tanggal 18 Maret 2018.

Suratiyah K. 1994. Konsep-konsep Kegiatan Off Farm. Populasi, 5(1): 1-14. 
JIIA, VOLUME 8 No 4, NOVEMBER 2020

http://jurnal.ugm.ac.id/populasi/article/downlo $\mathrm{ad} / 11348 / 8458$. Diakses pada tanggal 6 Oktober 2018.

Todaro MP. 1993. Pembangunan Ekonomi

Dunia Ketiga. Penerjemah Aminuddin.

Penerbit Ghalia Indonesia. Jakarta. 